\title{
STRUCTURAL STATE EFFECT ON MECHANICAL PROPERTIES AND ACOUSTIC EMISSION OF HIGH-PURITY TITANIUM AT DIFFERENT TYPES OF DEFORMATION
}

\author{
(D)Kseniya Kutniy*, (DIgor Kislyak**, (D)Alexander Kalchenko, (D)Petr Stoev, \\ Dikhail Tikhonovsky, (D) Pavel Khaimovich \\ National Science Center ,Kharkiv Institute of Physics and Technology” \\ 1, Akademichna St., 61108, Kharkiv, Ukraine \\ *E-mail:kutny@kipt.kharkov.ua,**E-mail:kislyak@kipt.kharkov.ua \\ Received May 21, 2019; accepted June 27, 2019
}

\begin{abstract}
The results on investigations of mechanical properties of high-purity titanium with grains ranging from tens of nanometers up to a few micrometers subjected to uniaxial tension, compression and microindenting are presented. Different structural states in highpurity titanium were formed by severe plastic deformation according to the scheme «upsetting - extrusion - drawing» in combination with annealing at temperatures of $250-550^{\circ} \mathrm{C}$ and quasi-hydrostatic extrusion at room and liquid nitrogen temperatures. The values of yield strengths and microhardness for samples of high-purity titanium with grains of different sizes are determined. It was shown that the combination of severe plastic deformation with cryogenic quasi-hydrostatic extrusion allowed to create high-purity nanocrystalline titanium with high mechanical properties. The obtained experimental data were analyzed for the implementation of the Hall-Petch relation and discrepancy between the values of yield strengths in tension and compression (strength differential or S-D effect). Satisfactory fulfillment of the Hall-Petch relation for high-purity titanium in the whole range of the studied grain size values was shown and a noticeable difference in the yield values for compression and tension was found. The values of the coefficients in the Hall-Petch equation for deformation by tension, compression and microindenting were determined. These coefficients are noticeably lower than the corresponding values for the industrial grades of titanium, i.e. in high-purity titanium, the grain boundaries are weaker barriers for moving dislocations than in the industrial titanium, whose boundaries are enriched with impurities. The features of the acoustic waves emission during compression of samples in various structural states were studied. It was concluded that the deformation of titanium in all the investigated structural states was carried out by dislocation slip.
\end{abstract}

KEY WORDS: high-purity titanium, nanostructure, tension and compression, Hall-Petch relation, acoustic emission

Titanium and its alloys are important materials for both commercial and medical purposes [1,2]. In particular, high-purity titanium and commercial grade titanium meet virtually all the requirements for the materials of medical implants according to the criteria of biocompatibility, corrosion resistance, hypoallergenicity, and absence (especially in high-purity titanium) of toxic elements [3]. However, the strength level of high alloys seems hardly achievable in pure metals (including titanium). Currently, the only way to increase the strength properties of pure titanium is to create fundamentally new structural states in it, which can be realized using the technology of extreme effects on solids [4]. Such effects include severe plastic deformation (SPD) and deformation at low (cryogenic) temperatures, or cryodeformation (CD) [4]. To obtain ultra-fine grains and extremely high strength characteristics, it seems natural to combine both considered methods of extreme impact on the material (SPD and CD) in the same technological chain [4]. Many schemes for the implementation of SPD [5-10] and CD [11-15] have been proposed. In the case of titanium, such a combination was realized in [12-14]. The SPD application by the method of «upsetting-extrusion-drawing» with subsequent additional drawing at liquid nitrogen temperature [13] allowed to obtain a wire from iodide titanium with the ultimate tensile strength of $1250 \mathrm{MPa}$, which is, apparently, one of the highest values for the material of a given purity. This strength is conditioned by small grain size, high uniformity of the grain structure and presence of highangle boundaries. In [16] the role of the initial grain size of high-purity titanium samples, obtained by the SPD method and subsequent annealing, was studied in the evolution of their structure and variation of their properties under the impact of CD by the quasi-hydrostatic extrusion (QHE) method at liquid nitrogen temperature. Such a low-temperature deformation resulted in grains refinement in the high-purity sub-microcrystalline titanium up to nanolevel, i.e. to the size of grains less than $100 \mathrm{~nm}$.

At the same time, the information about the regularities of the variations in the properties of titanium subject to the grain size, and about the mechanisms of metal deformation in the region of ultra-small grains is contradictory. It is known that the yield strength of many metals and alloys increases with the decrease in the grain size according to the known Hall-Petch relation $\sigma=\sigma_{0}+k d^{-1 / 2}$ [17]. In some works the classical linear dependence $\sigma\left(d^{-1 / 2}\right)$ was found, in the others some facts about the absence of $\sigma$ dependence on the grain size were noted, as well as the presence of the grain size interval, where a decrease in the yield strength with the decrease in the grain size was observed (the so-called "inverse" or "anomalous" Hall-Petch relation) [18]. Violation of the Hall-Petch law may be caused by a change in the basic mechanism of the material deformation. In this regard, it is of interest to study the mechanical properties of highpurity titanium when varying the grain size from tens of nanometers to several micrometers.

Besides, it is known $[19,20]$ that in some materials in the process of deformation the so-called S-D effect is observed, which lies in the different yield strengths when they are tested in uniaxial tension and uniaxial compression. We have no reference data about the influence of the grain size on the amount of this effect in the high-purity titanium. 
Particular data on the mechanisms of metals and alloys deformation is given by acoustic emission (AE). The acoustic emission waves emitted in the course of the material deformation represent the processes of its dynamic adjustment and are determined by both characteristics of the material itself (structure, chemical and phase composition, etc.) and the conditions of its loading. However, the acoustic emission in the process of titanium deformation was studied, mainly, using the commercial grade VT1-0 titanium [21-23] in the standard coarse-grained state [24-26].

The objective of this work was to study the influence of the structural state of high-purity titanium, obtained by various methods (SPD, CD, annealing), on its mechanical properties in tension, compression and microindentation tests, as well as to study the characteristics of the acoustic emission in the process of the samples compression at room temperature.

\section{MATERIALS AND RESEARCH METHODS}

For the research iodide titanium was used, whose impurities content, according to the certificate, was as follows (wt.\%): $\mathrm{O}-0.01, \mathrm{~N}-0.01, \mathrm{C}-0.01, \mathrm{Si}-0.009, \mathrm{Fe}-0.005, \mathrm{Ni}-0.005, \mathrm{Mg}-0.004, \mathrm{Mn}-0.004, \mathrm{Al}-0.005, \mathrm{Cr}-$ 0.005 . After double electron beam remelting in high $\left(1.3 \cdot 10^{-4} \mathrm{~Pa}\right)$ vacuum, the hardness of the obtained ingot was $\mathrm{H}_{\mathrm{B}} \approx 1.13 \mathrm{GPa}$. The ratio of the electrical resistances at temperatures $293 \mathrm{~K}$ and $77 \mathrm{~K}$ was $\mathrm{R}_{293} / \mathrm{R}_{77}=9.62$. The severe plastic deformation was realized in two stages. At the first stage the upsetting-extrusion of the initial ingot and its subsequent drawing into the wire rod were carried out [27]. In this case the ingot was upset from $\varnothing 43 \mathrm{~mm}$ to $\varnothing 48.5 \mathrm{~mm}$ at room temperature (true, or logarithmic, deformation $e_{l}=0.24$ ). Then, the obtained sample was placed into the preheated muffle furnace, heated to temperature $\mathrm{T}=600^{\circ} \mathrm{C}$ (the heating process took $20-25$ minutes), transported to the extrusion container, preheated to $250^{\circ} \mathrm{C}$, and extruded to $\varnothing 28 \mathrm{~mm}\left(e_{2}=1.10\right)$. One more extrusion to $\varnothing 10 \mathrm{~mm}\left(e_{3}=2.20\right)$ was performed in the same way as the first one, with the only difference, that the sample was heated up to $550^{\circ} \mathrm{C}$. The obtained wire rod with $\varnothing 10 \mathrm{~mm}$ was drawn to $\varnothing 5 \mathrm{~mm}$ at room temperature $\left(e_{4}=1.39\right)$. The total true deformation was $e_{S P D}=e_{1}+e_{2}+e_{3}+e_{4}=4.93$.

The obtained rod with $\varnothing 5 \mathrm{~mm}$ was taken as the basis for the manufacture of the experimental samples: it was cut into samples $25 \mathrm{~mm}$ long, some of which were annealed in vacuum $1.3 \cdot 10^{-1} \mathrm{~Pa}$ at temperatures $T_{a n n}=250,300,350,450$, $550^{\circ} \mathrm{C}$ for one hour to achieve different structural states. Then the samples in the initial and annealed states were used both to study the microstructure and mechanical properties and to implement an additional stage of QHE deformation at liquid nitrogen and room temperatures (the QHE technique was described in $[28,29]$ ). The degree of QHE deformation for all the samples was the same and made about $45 \%$ (the true deformation $e_{5} \approx 0.6$ ). The total degree of deformation of the material, which was not subjected to the intermediate annealing, with QHE taken into account, made $e_{\text {total }} \approx 5.53$.

The samples obtained according to the "upsetting - extrusion - drawing up to $\varnothing 5 \mathrm{~mm}$ " scheme will be referred to as "SPD"-titanium, with the state specification (un-annealed, i.e., in the initial state, or annealed at the specific temperature $T_{a n n}$ ), the processes of quasi-hydrostatic extrusion and their results will be indicated as "QHE300" and "QHE77", according to the extrusion temperatures in Kelvins.

The samples microstructure was investigated by transmission electron microscopy method (electron microscope JEM-100 CX).

The microhardness $H_{\mu}$ of the samples was measured on the transverse sections using a PMT-3 microhardness tester with the load of $0.5 \mathrm{~N}$. The mechanical tests in compression and tension were carried out at room temperature on the universal 1958-U10-1 testing machine with the deformation rate of $2 \cdot 10^{-4} \mathrm{~s}^{-1}$. The samples for tension tests had a standard shape of dumbbells with the gage section diameter of $2 \mathrm{~mm}$ and length of $15 \mathrm{~mm}$; here the cylindrical samples with the diameter of $3 \mathrm{~mm}$ and height of about $4 \mathrm{~mm}$ were compressed.

In the process of the samples compression, the resulting acoustic emission (AE) was investigated. To record AE signals the eight-channel acoustic complex M400, developed at the Institute of Mechanical Engineering Problems of the National Academy of Sciences of Ukraine, was used, which allowed recording pulses of different amplitudes [30]. ZTP19 ceramic piezoelectric transducer $(180 \mathrm{kHz}$ resonance frequency) was pressed with a special holder with a constant force through a lubricant layer, which improved the acoustic contact, to the lower side of the sample-bearing platform. When testing samples, after a certain time interval (from 1 to $5 \mathrm{~s}$ ), the deformation parameters (applied load, grip displacement) and the number of $\mathrm{AE}$ pulses, which were received by each of the eight amplitude countersdiscriminators of the acoustic complex, were synchronously recorded. Collection, processing and analysis of experimental results were performed using a computer.

\section{EXPERIMENTAL RESULTS AND THEIR DISCUSSION Microstructure}

Electron-microscopic studies of cross sections of deformed rods $\varnothing 5 \mathrm{~mm}$ showed (Fig. 1a) that the SPD scheme application resulted in formation of the submicrocrystalline state, characterized by an average grain size (subgrain) of about $150 \mathrm{~nm}$ (while in the process of warm deformation the grains were refined to $225 \mathrm{~nm}$, the follow-up refinement was caused by drawing them at room temperature). In cross-section the grains have a non-equiaxial shape, and between them a low-angle misorientation prevails. In the longitudinal section of the rod the grains are strongly elongated in the 
direction of drawing, and their average size is $2-3$ times larger than that in the cross section. In the body of grains a rather high dislocation density is observed.

The samples, cut from the rod, were annealed isochronically for one hour in the temperature range of $250-550^{\circ} \mathrm{C}$. Annealing at temperatures up to $300^{\circ} \mathrm{C}$ does not cause a noticeable change in the grain size, but leads to formation of clearer grain boundaries, the dislocation density in them decreases (Fig. 1b). In this case, predominantly small-angle grain misorientation is preserved.

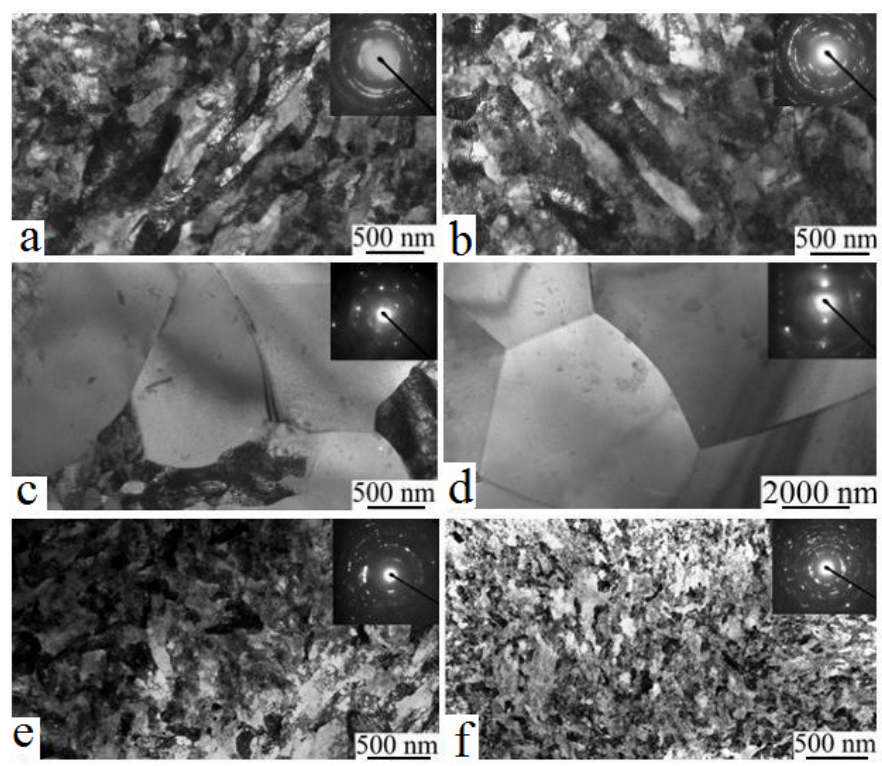

Fig.1. Microstructure of high-purity titanium after SPD, annealing at different temperatures and QHE at room and at liquid-nitrogen temperatures: (a) - SPD; (b) - SPD+annealing at $300^{\circ} \mathrm{C}$; (c) - SPD+annealing at $350^{\circ} \mathrm{C}$; (d) - SPD+annealing at $550^{\circ} \mathrm{C}$, (e) SPD+QHE300; (f) - SPD+QHE77.

An increase in the annealing temperature to $350^{\circ} \mathrm{C}$ leads to the onset of the recrystallization process and formation of a bimodal structure with the average grains size of $150 \mathrm{~nm}$ and $0.6 \mu \mathrm{m}$ (Fig.1c). Further annealings at $450^{\circ}$ and $550^{\circ} \mathrm{C}$ (Fig. $1 \mathrm{~d}$ ) lead to an intensification of the recrystallization process: the developed grains, having large misorientation and clear thin boundaries, are of the average size of 4 and $9 \mu \mathrm{m}$ in these samples, respectively.

The microstructure transformation by QHE was studied on the SPD-titanium samples with the initial average grain size of $150 \mathrm{~nm}$ (Fig.1a) and on the SPD+annealing samples. The electron-microscopic studies have shown that QHE causes refinement of the grain, but the degree of this refinement substantially depends on the treatment temperature. So, after QHE300 the structure of high-purity SPD-titanium changed a little as compared to that in the initial state: the average grain size made $130 \mathrm{~nm}$ (Fig.1e). An increased dislocation density was observed inside the grains. At the same time, QHE77 resulted in a significant refinement of the structure, the average grain size decreased by half and made $75 \mathrm{~nm}$ (Fig.1f). In this case the grains in the cross section of the sample became more equiaxial. The high density of point reflections in the micro-diffraction pattern also indicates to a significant refinement of the grains.

\section{Mechanical properties}

Figure 2 presents the obtained data on yield strength value $\sigma_{0.2}$ of the samples in the tension and compression studies. The behavior of the dependences turned out to be identical: the $\sigma_{0.2}$ value in samples of the "SPD+annealing" series dropped under compression as sharply as under tension (Fig. 2, curves 1). Quasi-hydrostatic extrusion significantly reduces the role of the preliminary annealing temperature, and this reduction is much more clearly marked at QHE77 (curves 3) than at QHE300 (curves 2). In this case, as can be seen, titanium, which has been treated according to the "SPD+QHE77" scheme, gives the highest value of the yield strength under compression $\sigma_{0.2} \approx 810 \mathrm{MPa}$.

The hatched areas in Fig. 2 visually demonstrate the above mentioned S-D effect: it can be seen, that in all states of the high-purity titanium under study the yield strength values under compression are higher than those under tension. The observed difference in the values of yield strengths under uniaxial compression $\left(\sigma_{0.2 c}\right)$ and tension $\left(\sigma_{0.2 t}\right)$ determines the value of relative S-D effect $\Delta$. It was calculated by the formula [20]:

$$
\Delta=\frac{2\left(\sigma_{0.2 c}-\sigma_{0.2 t}\right)}{\sigma_{0.2 c}+\sigma_{0.2 t}} \cdot 100 \%
$$

The $\Delta$ values calculated by formula (1) are presented in Fig.3. As can be seen, the nature and value of the S-D effect depend on the structural state of the material. In the initial SPD samples and SPD $+(350,450)^{\circ} \mathrm{C}$ samples, the value of $\Delta$ is approximately constant and makes about $10 \%$, and then it grows sharply to $\approx 21 \%$ for the SPD $+550^{\circ} \mathrm{C}$ samples. The QHE300 treatment results in a more uniform, but inverse change in the value of the effect: from 
maximum $\triangle \approx 22 \%$ for the samples $\mathrm{SPD}+\mathrm{QHE} 300$ to $\triangle \approx 5 \%$ for the samples $\mathrm{SPD}+550^{\circ} \mathrm{C}+\mathrm{QHE} 300$. And finally, the QHE77 treatment results in the loss of any significant dependence of $\Delta$ on the previous history of the samples: the effect is almost constant, within the level of $\leq 10 \%$.

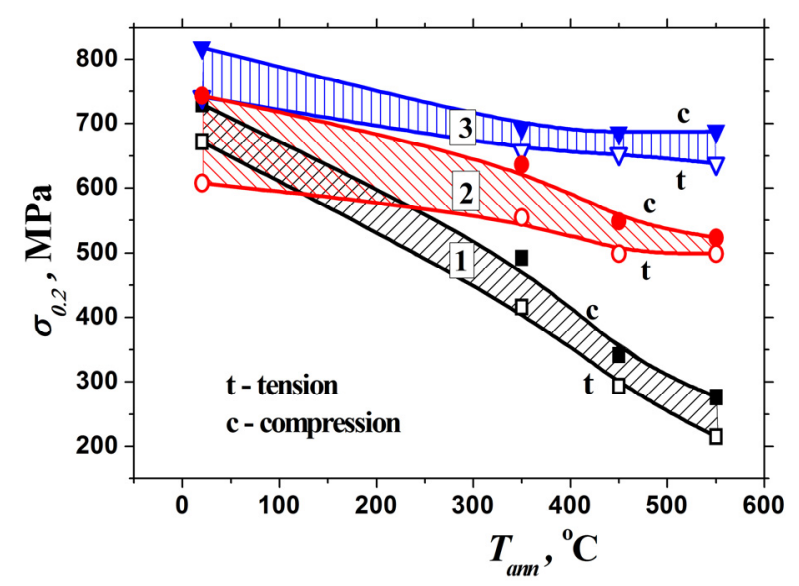

Fig.2. Dependences of the titanium samples yield strengths in compression and tension on the annealing temperature and processing scheme: 1 - SPD+annealing; 2 SPD+annealing+QHE300; 3 - SPD+annealing+QHE77.

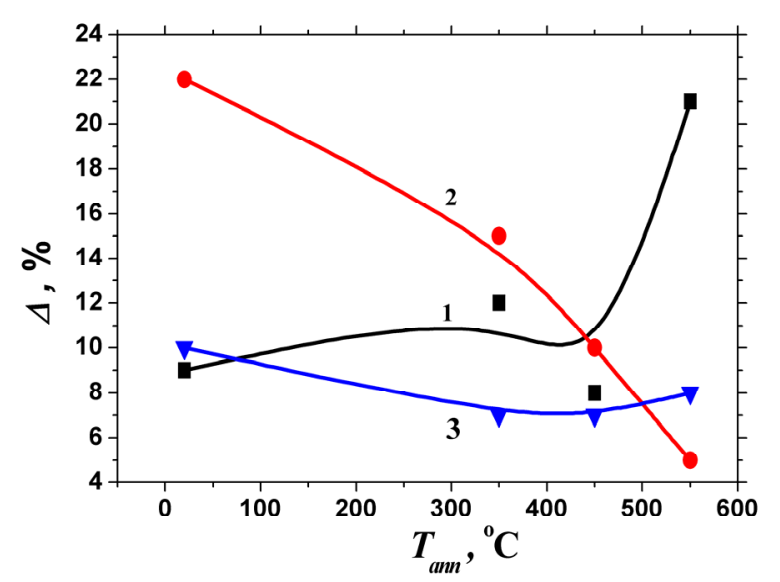

Fig.3. Dependences of the relative value of S-D effect on the annealing temperature and processing scheme: 1 SPD+annealing; $2-$ SPD+annealing+QHE300; $3-$ SPD+annealing+QHE77.

The authors [31] reported on the observation of the S-D effect in commercially pure titanium, where its maximum value corresponded to a coarse-grained state (the average grain size was about $15 \mu \mathrm{m}$ ) and made $\Delta=32 \%$. Here, the value of $\Delta$ decreased with grain size decreasing. Apparently, such a high value of $\Delta$ may be due to the increased oxygen content in their material (up to $0.34 \mathrm{wt} . \%$, in contrast to $0.01 \mathrm{wt} . \%$ in our titanium). As is known, oxygen strongly affects the titanium mechanical properties: it increases strength, reduces ductility, and increases the value of S-D effect [32]. In our samples a high $\triangle \approx 21 \%$ value was observed for the samples annealed at $550^{\circ} \mathrm{C}$ and having a fully recrystallized structure and the grain size of $9 \mu \mathrm{m}$. At the same time, however, approximately the same $\Delta \approx 22 \%$ value was determined for the SPD+QHE300 samples having the small grain size of $\approx 130 \mathrm{~nm}$. This may mean that the grain size is not the only parameter that determines the value of $\Delta$. In [16] it was shown that despite the fact, that the quasihydrostatic extrusion of SPD samples at $300 \mathrm{~K}$ (SPD+QHE300) results in some grain refinement (130 nm as compared to $150 \mathrm{~nm}$ for the SPD samples), the yield strength $\sigma_{0.2 t}$ decreases. It was suggested that one of the reasons for this anomalous effect could be a change in the stressed state and density of dislocations. Perhaps these factors also affect the value of the S-D effect.

The obtained data on the mechanical characteristics and grain size in the studied samples of high-purity titanium allowed representing the relationships between them in the Hall-Petch coordinates for the yield strengths in tension (Fig.4a), in compression (Fig.4b) and for microhardness (Fig.5).
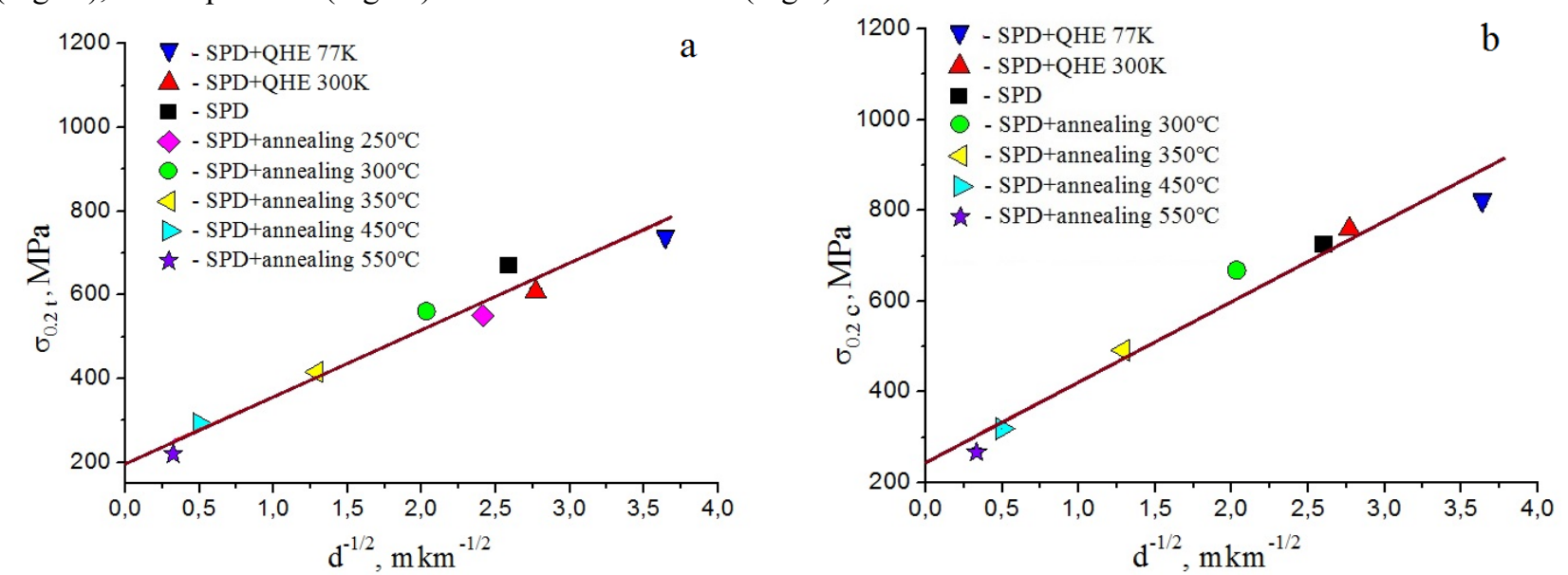

Fig.4. Dependencies of yield strengths in tension (a) and compression (b) on the grain size of the high-purity SPD-titanium after various heat treatments and quasi-hydrostatic extrusion at room temperature and liquid nitrogen temperature.

The presented graphs show that, despite the available scatter of data, in general the Hall-Petch ratio in the case of high-purity titanium is satisfactorily performed over the entire range of grain sizes from $75 \mathrm{~nm}$ (SPD+QHE77) to $9 \mu \mathrm{m}$ $\left(\mathrm{SPD}+\right.$ annealing at $\left.550^{\circ} \mathrm{C}\right)$. This means that the most likely mechanism of deformation in the entire specified region is dislocation slip [33]. 


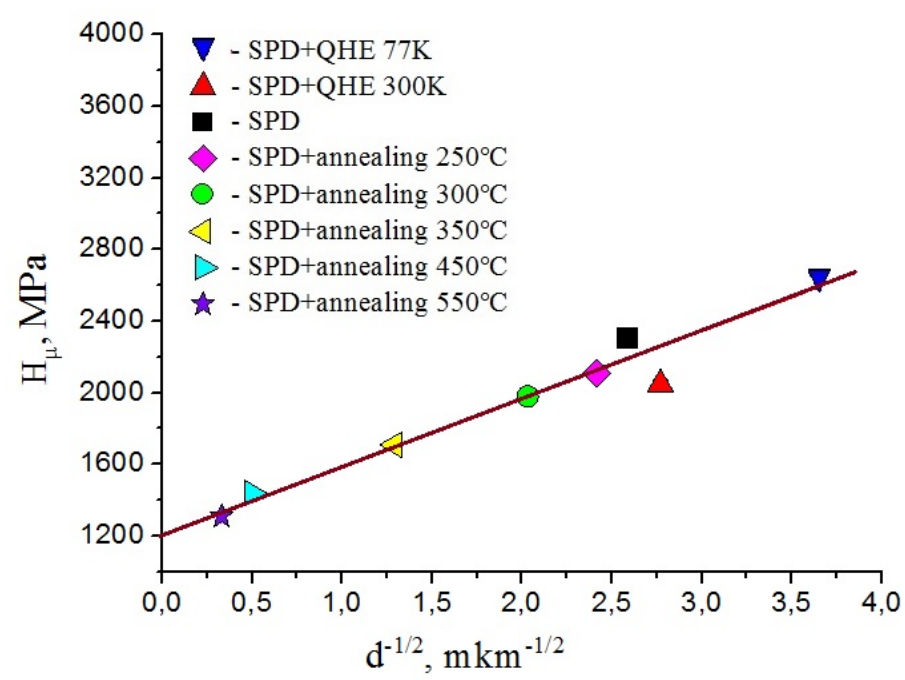

Fig.5. Dependence of microhardness on the grain size of high-purity SPD-titanium after various heat treatments and quasi-hydrostatic extrusion at room temperature and liquid nitrogen temperature.

Note, that the coefficients in the Hall-Petch equation for the yield strength in tension $\sigma_{0.2 t}=\sigma_{0 t}+k_{t} \cdot d^{-1 / 2}$ $\left(k_{t}=0.155 \mathrm{MPa} \cdot \mathrm{m}^{1 / 2}\right)$, in compression $\sigma_{0.2 \mathrm{c}}=\sigma_{0 \mathrm{c}}+k_{c} \cdot d^{-1 / 2}\left(k_{c}=0.178 \mathrm{MPa} \cdot \mathrm{m}^{1 / 2}\right)$ and for microhardness $H_{\mu}=H_{0}+k_{h} \cdot d^{-1 / 2}$ $\left(k_{h}=0.375 \mathrm{MPa} \cdot \mathrm{m}^{1 / 2}\right)$ turned out to be much lower than the reference data obtained for the commercial grades of titanium $\left(k_{t}\right.$ makes $0.53 \mathrm{MPa} \cdot \mathrm{m}^{1 / 2}$ [18] and $0.21 \mathrm{MPa} \cdot \mathrm{m}^{1 / 2}$ [33] for titanium VT1-00, $k_{h}$ for this grade of titanium makes $0.65 \mathrm{MPa} \cdot \mathrm{m}^{1 / 2}[33]$, and for titanium VT1-0 $k_{h}$ makes $0.4 \mathrm{MPa} \cdot \mathrm{m}^{1 / 2}[34], 0.7 \mathrm{MPa} \cdot \mathrm{m}^{1 / 2}[35]$ and $\left.0.4 \mathrm{MPa} \cdot \mathrm{m}^{1 / 2}[36]\right)$. As long as these coefficients characterize the "ease" of plastic deformation propagation through the grain boundaries, i.e. "transparency" of the grain boundaries for the dislocations transition from grain to grain, this result indicates to the fact, that in high-purity titanium the "transparency" of boundaries is higher than in the commercial titanium, in which the boundaries are enriched with impurities.

The values of $\sigma_{0 \mathrm{t}}, \sigma_{0 \mathrm{c}}$ and $H_{0}$ in the Hall-Petch equations characterize the resistance (friction) stress of the crystal lattice to the dislocation slip. For the studied titanium these values are $\sigma_{0 \mathrm{t}}=200 \mathrm{MPa}, \sigma_{0 \mathrm{c}}=250 \mathrm{MPa}$ and $H_{0}=1200 \mathrm{MPa}$. These parameters turned out also lower than those for the commercial grades of titanium. Thus, according to the data by different authors, for VT1-00 $\sigma_{0 \mathrm{t}}$ makes $290 \mathrm{MPa}$ [33], for VT1-0, the values of $H_{0}$ are $1840 \mathrm{MPa}$ [33], $1500 \mathrm{MPa}$ [34], $1550 \mathrm{MPa}$ ) [35] and $1500 \mathrm{MPa}$ [36]. The lower values of these parameters in our titanium are due to the lower concentration of the impurity atoms in the crystal lattice, which make additional obstacles to the dislocations motion.

\section{Acoustic emission}

AE signal recording has shown, that the activity, the total amount of the recorded signals and the amplitude distribution of the signals depend on the structural state of titanium.

Figure 6 shows the AE activity curves of the titanium samples after severe plastic deformation and subsequent annealing at temperatures of 350 and $550^{\circ} \mathrm{C}$. A significant difference between these curves is observed. Thus, the AE activity of the SPD-titanium samples after a small growth in the initial part of the loading remains very low at further deformation.

The dependences of the AE activity after annealing of SPD-samples at temperatures of 350 and $550^{\circ} \mathrm{C}$ have quite a different character. In the stage of plastic deformation, the AE activity of these samples sharply grows, and maxima are observed on the AE curves; the absolute values of AE activity increase by an order of magnitude relative to the values at the elastic stress section. It can be seen, that the rise of $\mathrm{AE}$ activity in samples annealed at $350^{\circ} \mathrm{C}$ starts a little later than in the samples with $T_{a n n}=550^{\circ} \mathrm{C}$. It should also be noted, that AE both in the initial SPD-samples and in the annealed samples starts immediately after the deformation onset in the stage of elastic deformations.

Fig. 7 shows graphs (in absolute values) and histograms (in relative values) of the number of pulses, which were recorded by 8 counters. Each of the counters (channels) was adjusted to record the AE signal of certain amplitude. The upper and lower amplitudes of each counter (adjusted to the preamplifier input) were 10-20, 20-30, 30-40, 40-50, 50-60, 60-70, 70-80, and $>80 \mu \mathrm{V}$.

The analysis showed that histograms of the AE signals distribution in amplitudes had features related to the type of amplitude distribution and the quantitative ratio of high-amplitude AE signals to low-amplitude ones. Usually, in the case of plastic fracture of metals the amplitude distribution has an exponential form, and the number of low-amplitude signals always exceeds the number of high-amplitude ones. Violation of this rule in the process of material deformation is usually associated with a change in the deformation mechanism or the onset of the formation and propagation of cracks. In the tested SPD-titanium the amplitude distribution spectrum contains signals of both low and high amplitudes, but the number of low-amplitude signals is greater than that of the high-amplitude ones (see Fig. 7b). But for the 
samples SPD+annealing at $350^{\circ} \mathrm{C}$, the number of high-amplitude signals in the spectrum was significantly greater as compared to the number of low-amplitude AE signals. For the samples SPD+annealing at $550^{\circ} \mathrm{C}$ a sharp increase in the low-amplitude AE signals is observed in the spectrum, and the amplitude distribution is of exponential character (see Fig. 7a).

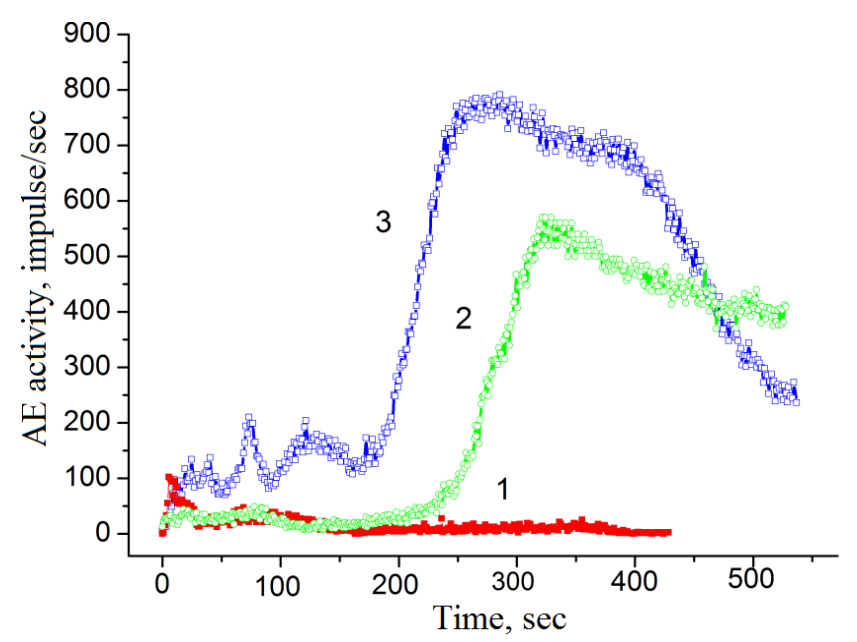

Fig.6. Dependence of AE activity on the titanium samples state: $1-\mathrm{SPD} ; 2-\mathrm{SPD}+$ annealing at $350^{\circ} \mathrm{C} ; 3-\mathrm{SPD}+$ annealing at $550^{\circ} \mathrm{C}$.
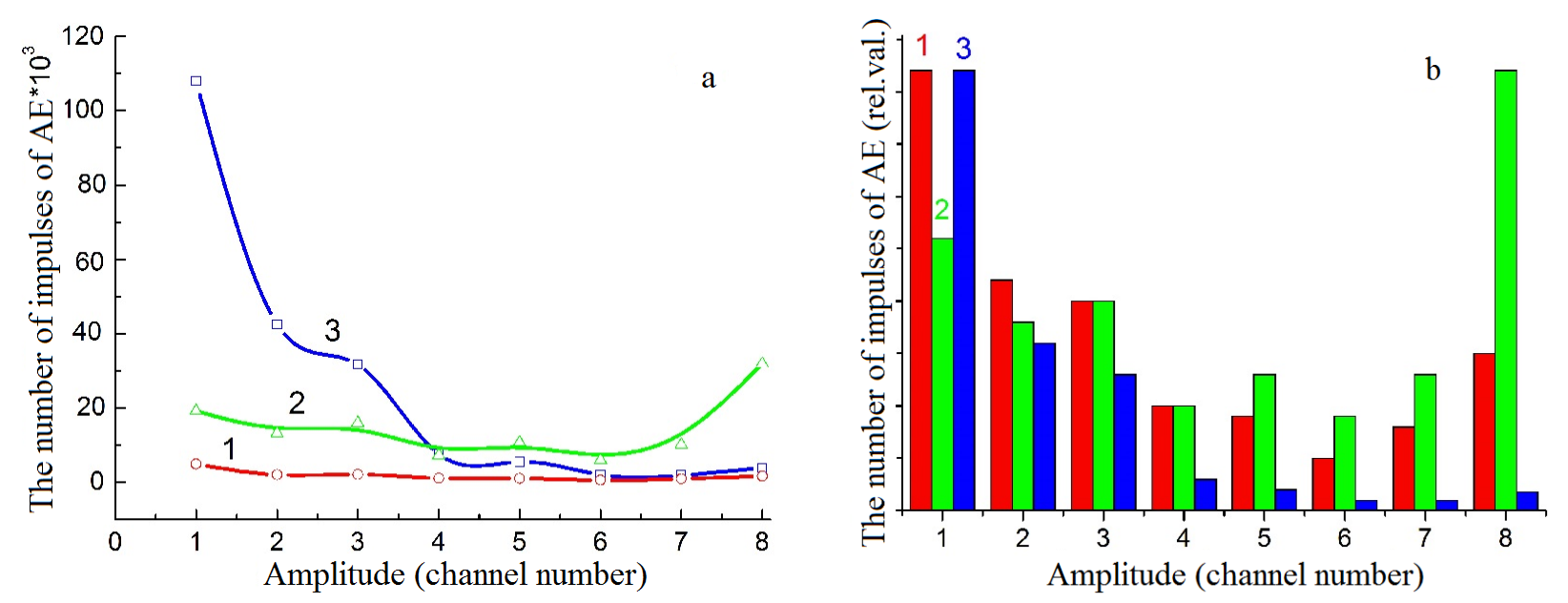

Fig.7. Dependencies of the number of recorded AE signals on their amplitude in absolute (a) and relative (b) units in titanium samples after treatment: (1) - SPD, (2) - SPD+annealing at $350^{\circ} \mathrm{C},(3)-\mathrm{SPD}+$ annealing at $550^{\circ} \mathrm{C}$.

The specific features of the $\mathrm{AE}$ activity dependence on the deformation of titanium samples during their loading (Fig. 6) are determined by the structural state of the tested samples. Let us analyze these characteristic properties.

As noted above, in the process of SPD a submicrocrystalline state of titanium is formed with an average grain (subgrain) size of about $150 \mathrm{~nm}$. Annealing at $350^{\circ} \mathrm{C}$ leads to the onset of the recrystallization process and to the formation of a bimodal structure with an average grain size of $150 \mathrm{~nm}$ and $0.6 \mu \mathrm{m}$; annealing at the temperature of $550^{\circ} \mathrm{C}$ leads to recrystallization and formation of grains of $9 \mu \mathrm{m}$ in size. The microhardness of the SPD titanium samples makes $H_{\mu}=2.3 \mathrm{GPa}$, and, after annealing at 350 and $550^{\circ} \mathrm{C}$, it is 1.7 and $1.36 \mathrm{GPa}$, respectively. Thus, the heat treatment of SPD titanium samples results in an increase in the grain size and a decrease in the hardening (hardness) of the metal.

Numerous experiments have shown, that the acoustic emission depends on the grain size in the metal: with the decrease of the grain size the $\mathrm{AE}$ signals generation also decreases [37]. This is due to the fact that, as the grain size decreases, the number of obstacles to dislocation slip, in the form of the grain boundaries, grows. A short distance of the dislocations sliding and an increase in the number of obstacles to their movement result in the decrease in the rate (and, hence, the energy) of the emitted AE pulses. This leads to a lower probability to detect the AE source when the grain size decreases. For the metals with very fine grains, the energy of the emitted pulses may be below the threshold of the equipment sensitivity, and the acoustic emission will not be observed until the sample is destroyed.

Hardening of titanium in the process of SPD and quasi-hydrostatic extrusion also results in a decrease in the AE activity. The effect of hardening on the activity of titanium AE is described in detail in [38]. 
Thus, the specific features of the AE activity curves for the SPD and SPD+annealing samples at temperatures of 350 and $550^{\circ} \mathrm{C}$ are determined by the grain size and the value of titanium hardening (hardness). Larger grain size and lower microhardness lead to the fact, that in the samples SPD+annealing at $550^{\circ} \mathrm{C}$ the plastic deformation starts at lower stress than in the SPD+annealing at $350^{\circ} \mathrm{C}$ samples (Fig. 6, curves 2 and 3 ).

The probable cause for the occurrence of specific amplitude distribution of $\mathrm{AE}$ in titanium samples SPD+annealing at $350^{\circ} \mathrm{C}$, which have a bimodal structure, can be shear bands. Usually, the high-amplitude pulses are attributed to propagation of twins, the number and "power" of which increase with the grain size rise. SPD-titanium is characterized by submicron size grains, in which twinning is completely absent. Probably, the high level of the internal stresses, which is inherent in SPD-titanium, is summed up with the applied external stresses, what results in the formation of a large number of shear bands at the stage of the developed plastic deformation [39]. Elimination of these stresses by annealing (in our case it is annealing of SPD-titanium at $550^{\circ} \mathrm{C}$ ) prevents the occurrence of shear bands, while the grain growth leads to the fact, that the character of the change in the AE low-amplitude component of the titanium, annealed at $550^{\circ} \mathrm{C}$ (Fig. 6, curve 3), is similar to the change in the activity that was observed when studying the acoustic emission of industrial sheet titanium in the process of its deformation [39]. It is determined by the dislocation mechanism of deformation and the structural features: the distribution of impurities and the degree of dislocations pinning.

To gain a more complete understanding of the detected specific features of AE signals amplitude distribution in titanium samples after SPD and subsequent annealing, further studies are required.

\section{CONCLUSIONS}

1. Mechanical tests on uniaxial tension, compression and microindentation of high-purity titanium samples in different structural states, formed by severe plastic deformation in combination with annealing and quasi-hydrostatic extrusion at room and liquid nitrogen temperatures, were carried out. The microstructure of the samples is characterized by an average grain size, which varies from 9 microns to $75 \mathrm{~nm}$. The values of the yield strengths and the microhardness values for the samples with different grain sizes were determined.

2. In the obtained samples a noticeable difference was found in the values of the yield strength in compression and tension, the so-called S-D effect. The relative value of the S-D effect, $\Delta$, depends on the structural state of the material and varies from about $10 \%$ to $21-22 \%$. At the same time, there is no unambiguous relation between the grain size and the value of $\Delta$.

3. Satisfactory performance of the Hall-Petch relation for the high-purity titanium in the whole range of the studied grain size values was shown. This fact indicates that deformation at the initial stage is realized by one mechanism dislocations glide. The values of the coefficients in the Hall-Petch equation for tension deformation $\left(k_{t}=0.155 \mathrm{MPa} \cdot \mathrm{m}^{1 / 2}\right)$, compression $\left(k_{c}=0.178 \mathrm{MPa} \cdot \mathrm{m}^{1 / 2}\right)$ and for microindentation $\left(k_{h}=0.375 \mathrm{MPa} \cdot \mathrm{m}^{1 / 2}\right)$ were determined. These coefficients are noticeably lower, than the corresponding values for the commercial grades of titanium, i.e., in high-purity titanium grain boundaries are weaker barriers for moving dislocations. Also, the values of parameters $\sigma_{0}$ and $H_{0}$, which characterize the lattice resistance to the dislocation glide, turned out to be lower.

4 Acoustic emission of the high-purity titanium samples in various structural states was studied in the process of deformation by uniaxial compression. The analysis of the AE activity dependence on the degree of deformation and the nature of the amplitude distribution confirms the dislocation mechanism of plastic deformation of nano- and submicrocrystalline titanium samples. In this case, the presence of a significant number of high-amplitude AE signals in the samples with a bimodal microstructure, obtained by severe plastic deformation and annealing at $350^{\circ} \mathrm{C}$, may be due to the formation of shear bands.

\section{ORCID IDs}

Kseniya Kutniy (iD https://orcid.org/0000-0002-9328-1336, Igor Kislyak Đhttps://orcid.org/0000-0001-5016-8133, Alexander Kalchenko Dhttps://orcid.org/0000-0003-0856-1868, Petr Stoev Dhttps://orcid.org/0000-0001-7942-5850, Mikhail Tikhonovsky $@$ https://orcid.org/0000-0001-5889-0366, Pavel Khaimovich $@$ https://orcid.org/0000-0002-2523-9726

\section{REFERENCES}

[1] H.J. Rack and Qazi, Mater. Sci. Eng. C. 26, 1269 (2006).

[2] R.Z. Valiev, I.P. Semionova, V.V. Latyshev, A.V. Shcherbakov, E.B. Yakushina, Российские нанотехнологии [Russian Nanotechnologies]. 3(9-10), 106 (2008). (in Russian).

[3] Биосовместимость [Biocompatibility], (Ed. by V.I.Sevastianov, IC VNIIIgeosystem, Moscow, 1999), p. 368. (in Russian).

[4] A.M.Glezer, УФН [Physics-Uspekhi (Advances in Physical Sciences)]. 182, 559 (2012). (in Russian).

[5] R.Z. Valiev, I.A. Aleksandrov, Объемные наноструктурные материаль: получение, структура и свойства [Вицk Nanostructured Materials: Mnufacturing, Structure, and Properties], (Akademkniga, Moscow, 2007), p. 398. (in Russian).

[6] A.A. Popov, R.Z. Valiev, I.Yu. Pyshmintsev, S.L. Demakov, A.G. Illarionov, ФМM [The Physics of Metals and Metallography]. 83, 127 (1997). (in Russian).

[7] R.Z. Valiev, A.V. Sergueeva, and A.K. Mukherjee, Scripta Mater. 49, 669 (2003).

[8] S.P.Malysheva, G.A. Salishchev, R.M. Galeyev, V.N.Danilenko, M.M. Myshliayev, A.A.Popov, ФMM [The Physics of Metals and Metallography]. 95, 98 (2003). (in Russian).

[9] Y. Beygelzimer, V. Varyukhin, D. Orlov, B. Efros, V. Stolyarov, and H. Salimgareyev, in: TMS Annual Meeting, Ultrafine Grained Materials II, (Washington, 2002), p. 43. 
[10] A.Yu. Yeroshenko, Yu.P. Sharkeyev, A.I. Tolmachov, G.P.Korobitsyn, V.I.Danilov, Перспективные материалы [Advanced Materials]. 7, 107 (2009). (in Russian).

[11] I.M. Neklyudov, V.I. Sokolenko, L.A. Chirkina, G.P. Kovtun, I.F. Borisova, V.V. Kalinovskiy, D.G. Malykhin, E.N. Metolidi, V.S. Okovit, Металлофиз. и новейшие технологии [Metallofizika i Noveishie Tekhnologii]. 29, 359 (2007). (in Russian).

[12] E.D. Tabachnikova, A.V. Podolskiy, S.N. Smirnov, M.A. Tikhonovsky, P.A. Khaimovich, N.I. Danylenko, S.A. Firstov, Вісник Харківського національного університету, Серія «Фізика» [Visnyk Kharkivs'kogo Natsional'nogo Universytetu, Seriya "Fizyka"]. 28, 63 (2018). (in Ukrainian).

[13] M.A. Tikhonovskii, I.F. Kislyak, O.I. Volchok, T.Yu. Rudycheva, V.G.Yarovoi, A.V. Kuz'min, N.V. Kamyshanchenko, and I.S. Nikulin, ФТВД [Physics and Technology of High Pressures]. 18, 96 (2008). (in Russian).

[14] K.V. Kutniy, O.I. Volchok, I.F. Kislyak, M.A. Tikhonovsky, and G.E. Storozhilov, Mater. Sci. Engineering Technology (Mat.wiss.u.Werkstofftech.). 42, 114 (2011).

[15] V.A. Moskalenko, A.R. Smirnov, and A.V. Moskalenko, ФHT [Low Temp. Phys.]. 35, 1160 (2009). (in Russian).

[16] M.A. Tikhonovsky, P.A. Khaimovich, K.V. Kutniy, I.F. Kislyak, V. S. Okovit, and T.Yu. Rudycheva, ФHT [Low Temp. Phys.]. 39, 1261 (2013). (in Russian).

[17] P. Lukáč, Z. Trojanová, Materials Engineering. 18, 110 (2011).

[18] A.V. Nokhrin, V.N. Chuvil'deyev, E.S. Smirnova et. al. Механические свойства нано- и микрокристаллических металлов. [Mechanical Properties of Nano- and Microcrystalline Metals] (NNGU, Nizhniy Novgorod, 2007), p. 46. (in Russian).

[19] J.P. Hirth and M. Kohen, Met. Trans. 1, 3 (1970).

[20] C.A. Pampillo, L.A. Davis, and J.C.M. Li, Scripta Met. 6, 765 (1972).

[21] H. Tanaka and R. Horiuchi, Scripta Met. 9, 777 (1975).

[22] M. Frizel and S.H. Carpenter, Metall. Trans. 15A, 1849 (1984).

[23] J.R. Kennedy, Scripta Met. 16, 525 (1982).

[24] P.I. Stoev, I.I. Papirov, and V.I. Moshchenok, Вопросы атомной науки и техники, Серия: Вакуум, чистые материалы, сверхпроводники [Problems of Atomic Science and Technology. Section: Vacuum, Pure Materials and Superconductors]. 15(1), 15 (2006). (in Russian).

[25] P.I. Stoev, I.I. Papirov, Вопросы атомной науки и техники, Серия: Вакуум, чистые материалы, сверхпроводники [Problems of Atomic Science and Technology. Section: Vacuum, Pure Materials and Superconductors]. 16(4), 119 (2007). (in Russian).

[26] E.Z. Kayumova, V.V. Astanin, and A.A. Girfanova, Письма о материалах [Materials Letters]. 3, 193 (2013). (in Russian).

[27] I.F. Kislyak, K.V. Kutniy, M.A. Tikhonovsky, A.I. Pikalov, T.Yu. Rudycheva, N.F. Andrievskaya, and R.L. Vasilenko, ФТВД [Physics and Technology of High Pressures]. 23, 53 (2013). (in Russian).

[28] P.A. Khaimovich, Low Temperature Physics. 44 (5), 349 (2018).

[29] P.A. Khaimovich, Перспективные материалы [Advanced Materials]. 3, 363 (2009). (in Russian).

[30] I.I. Papirov, P.I. Stoev, G.F.Tikhinskiy, M.I. Palatnik, M.B. Mileshkin, and E.I. Muzyka, ФMM [The Physics of Metals and Metallography]. 57(2), 1037 (1984). (in Russian).

[31] E.D. Tabachnikova, V.Z. Bengus, A.V. Podolskiy, S.N. Smirnov, and R.Z.Valiev, Кристаллография [Crystallography]. 54, 1119 (2009). (in Russian).

[32] T.P. Cherniayeva, A.I. Stukalov, and V.M. Gritsyna, BAHT [Problems of Atomic Science and Technology. Section: Vacuum, Pure Materials and Superconductors]. 1, 96 (2002).

[33] M.M. Myshliayev, S.Yu. Mironov, Физика твердого тела [Solid State Physics]. 44(4), 711 (2002). (in Russian).

[34] Yu.P. Sharkeev, I.A. Kurzina, I.A. Bozhko, and A.Yu. Eroshenko, in: 10-th International Conference on Modification of Materials with Particle Beams and Plasma Flows, Oral Session: Beam and Plasma Nanoscience and Nanotechnology, (Tomsk, Russia, 2010), pp. 705-708. (in Russian).

[35] A.A. Chabanets, in: XVII Международная научно-практическая конференция «Современные техника и технологии», Секиия 6: Материаловедение [XVII International Scientific and Commercial Conference "Modern Engineering @ Technologies". Section 6: Materials Science] (Tomsk, Russia, 2012), pp. 261-262. (in Russian).

[36] I.A. Kurzina, I.A. Bozhko, M.P. Kalashnikov et. al., Материаловедение [Materials Science]. 5, 48 (2010). (in Russian).

[37] V.A. Greshnikov, Yu.V. Drobot, Акустическая эмиссия. Применение для испытаний материалов и изделий [Асоиstic Emission: Application for Materials and Products Testing]. (Mashinostroyeniye, Moscow, 1974), p. 368. (in Russian).

[38] P.I. Stoev, I.I. Papirov, Металлофизика [Physics of Metals]. XIII (10), 28 (1991). (in Russian).

[39] M.A. Meyers, A. Mishra, and D.J. Benson, Progress in Materials Science. 51, 427 (2006).

\section{ВПЛИВ СТРУКТУРНОГО СТАНУ НА МЕХАНІЧНІ ВЛАСТИВОСТІ ТА АКУСТИЧНУ ЕМІСІЮ ВИСОКОЧИСТОГО ТИТАНУ ЗА РІЗНИХ ВИДІВ ДЕФОРМАЦЇ̈}

\section{К.В. Кутній, І.П. Кісляк, О.С. Кальченко, П.І. Стоєв, М.А. Тихоновський, П.О. Хаймович}

Національний науковий центр «Харківський фізико-технічний інститут» вул. Академічна 1, 61108, м. Харків, Україна

Представлені результати дослідження механічних властивостей високочистого титану з розмірами зерен від десятків нанометрів до кількох мікрометрів за одноосного розтягнення, одноосного стискання і мікроіндентування. Різні структурні стани в високочистому титані були сформовані шляхом інтенсивної пластичної деформації за схемою «осаджуваннявидавлювання-волочіння» в поєднанні з відпалами при температурах $250-550^{\circ} \mathrm{C}$ і квазігідроекструзією при кімнатній температурі та температурі рідкого азоту. Визначено значення меж плинності і величини мікротвердості для зразків високочистого титану з різним розміром зерна. Показано, що поєднання інтенсивної пластичної деформації та кріогенної квазігідроекструзії дозволило створити високочистий нанокристалічний титан з високими механічними властивостями. Дані експериментів проаналізовані щодо виконання співвідношення Хола-Петча та розбіжностей величин меж плинності при стисканні та розтягненні (S-D ефект). Показано задовільне виконання співвідношення Хола-Петча для високочистого титану 
в усій області досліджених значень розміру зерна і встановлено помітне розходження у величинах меж плинності на стиснення і розтягнення. Визначено значення коефіцієнтів в рівнянні Хола-Петча для деформації розтягненням, стисненням i для мікроіндентування. Ці коефіцієнти помітно нижче відповідних значень для технічних сортів титану, тобто в високочистому титані границі зерен $є$ слабшими бар'єрами для рухомих дислокацій, ніж в технічному титані, у якого границі збагачені домішками. 3'ясовані особливості емісії акустичних хвиль за стискування зразків, що мають різний структурний стан. Зроблено висновок, що деформація титану в усіх досліджених структурних станах відбувається шляхом дислокаційного ковзання.

КЛЮЧОВІ СЛОВА: високочистий титан, наноструктура, стискання та розтягнення, співвідношення Хола-Петча, акустична емісія

\section{ВЛИЯНИЕ СТРУКТУРНОГО СОСТОЯНИЯ НА МЕХАНИЧЕСКИЕ СВОЙСТВА И АКУСТИЧЕСКУЮ ЭМИССИЮ ВЫСОКОЧИСТОГО ТИТАНА ПРИ РАЗЛИЧНЫХ ВИДАХ ДЕФОРМАЦИИ К.В. Кутний, И.Ф. Кисляк, А.С. Кальченко, П.И. Стоев, М.А. Тихоновский, П.А. Хаймович \\ Национальный научный центр «Харьковский физико-технический институт» ул. Академическая 1, 61108, г. Харьков, Украина}

Представлены результаты исследования механических свойств высокочистого титана с размерами зерен от десятков нанометров до нескольких микрометров при одноосном растяжении, одноосном сжатии и микроиндентировании. Различные структурные состояния в высокочистом титане были сформированы путем интенсивной пластической деформации по схеме «осадка-выдавливание-волочение» в сочетании с отжигами при температурах $250-550^{\circ} \mathrm{C}$ и квазигидроэкструзией при комнатной температуре и температуре жидкого азота. Определены значения пределов текучести и величины микротвердости для образцов высокочистого титана с различным размером зерна. Показано, что сочетание интенсивной пластической деформации $\mathrm{c}$ криогенной квазигидроэкструзией позволило создать высокочистый нанокристаллический титан с высокими механическими свойствами. Данные экспериментов проанализированы на предмет выполнения соотношения Холла-Петча и несовпадения величин пределов текучести при сжатии и растяжении (S-D эффект). Показано удовлетворительное выполнение соотношения Холла-Петча для высокочистого титана во всей области исследованных значений размера зерна и установлено заметное различие в величинах пределов текучести на сжатие и растяжение. Определены значения коэффициентов в уравнении Холла-Петча для деформации растяжением, сжатием и для микроиндентирования. Эти коэффициенты заметно ниже соответствующих значений для технических сортов титана, т.е. в высокочистом титане границы зерен являются более слабыми барьерами для движущихся дислокаций, чем в техническом титане, у которого границы обогащенные примесями. Определены особенности эмиссии акустических волн при сжатии образцов, имеющих различное структурное состояние. Сделан вывод о том, что деформация титана во всех исследованных структурных состояниях осуществляется дислокационным скольжением.

КЛЮЧЕВЫЕ СЛОВА: высокочистый титан, наноструктура, сжатие и растяжение, соотношение Холла-Петча, акустическая эмиссия 